\title{
Pozzolanic Activity of Old Volcanic Tuffs of Mako Area (Senegal-Oriental, West African Craton): An Economic and Environmental Interest
}

\author{
Matar Ndiaye1, Mahamadane Diène1, Mouhamadou Bassir Diop¹, Papa Malick Ngom² \\ ${ }^{1}$ I. S. T., BP: 5396, F Sciences et Techniques, Université Cheikh Anta Diop de Dakar, Dakar, Sénégal \\ ${ }^{2}$ Département de géologie, Faculté des Sciences et Techniques, Université Cheikh Anta Diop de Dakar, Dakar, Sénégal \\ Email: matar.ndiaye@ucad.edu.sn,mahamadane@netcourrier.com, mbassirdiop@gmail.com,papam.ngom@ucad.edu.sn
}

How to cite this paper: Ndiaye, M., Diène, M., Diop, M.B. and Ngom, P.M. (2019) Pozzolanic Activity of Old Volcanic Tuffs of Mako Area (Senegal-Oriental, West African Craton): An Economic and Environmental Interest. International Journal of Geosciences, 10, 225-237.

https://doi.org/10.4236/ijg.2019.103014

Received: January 30, 2019

Accepted: March 12, 2019

Published: March 15, 2019

Copyright $\odot 2019$ by author(s) and Scientific Research Publishing Inc. This work is licensed under the Creative Commons Attribution International License (CC BY 4.0).

http://creativecommons.org/licenses/by/4.0/

\begin{abstract}
The volcanic tuffs of Senegal-Oriental in Mako area are produced during a calc-alkaline volcanism which occurs in this region and which is dated from about 2.3 - $1.95 \mathrm{Ga}$. Despite their altered appearance, the X-Ray diffractions show mineral paragenesis: Quartz-Kaolinite-Illite and an important amorphous phase. On the Ternary Keil-Rankin diagram for the $\mathrm{CaO}-\mathrm{SiO}_{2}-\mathrm{Al}_{2} \mathrm{O}_{3}$ the volcanic tuffs of Mako area are situated between pozzolan and the fly ash. The difference between silica and lime is greater than $34 \%$ in these volcanic tuffs. In this study, they have been mixed with Portland cement to obtain pozzolanic cements respectively with $20 \%, 30 \%, 35 \%$ and $40 \%$ of addition of volcanic tuffs. The pozzolanic reactivity is highlighted by the compressive strength increase until 90 days of conservation in water. It supposes that the vitreous phase of the volcanic tuffs reacts with the free $\mathrm{CaO}(\mathrm{CaOf})$ of Portland cement to produce new hydrated minerals. This study has a positive economic and environmental impact. Because the time of grinding of pozzolanic cements is reduced. Also, the addition of volcanic tuffs reduces the production of clinker, then the $\mathrm{CO}_{2}$ emission.
\end{abstract}

\section{Keywords}

Old, Volcanic, Tuffs, Calc-Alkaline, X-Ray Diffractions, Amorphous,

Pozzolanic, Cements, Compressive Strength, Economic, Environmental

\section{Introduction}

Portland cement is the most common type of cement used in construction applications, but it is an expensive binder due to the high cost of production asso- 
ciated with the high energy requirements of the manufacturing process itself [1]. Raw materials such as limestone and clay are grinded and heated in a kiln at $1400^{\circ} \mathrm{C}-1450^{\circ} \mathrm{C}$ to form predominantly clinker, which is then finely ground together with additives such as gypsum to obtain Portland cement [11] [32] [41]. Also, the heating of the raw material produces important $\mathrm{CO}_{2}$ emission in the atmosphere. Therefore, to reduce the $\mathrm{CO}_{2}$ emission and the cost of binder, other cheap inorganic materials with cementitious properties such as natural pozzolans, waste products from industrial plants and silica fume can be used as a partial replacement for Portland cement [2] [11] [12] [13] [14] [20] [22] [23] [24] [26] [37] [39] [41] [44] [45].

The volcanic tuffs of Mako are produced during volcanic eruption dated from about 2.3 - $1.95 \mathrm{Ga}$ [3] [4] [5] [6] [7] [35]. In this paper, the potential use of these volcanic tuffs as a natural raw material in the production of pozzolanic cement is investigated. In Senegal the production of Portland cement is very expensive associated with the important $\mathrm{CO}_{2}$ emission. To provide all people to access to the cement it is very important to test new raw material. In this study, the physical, chemical and mineralogical characteristics of the volcanic tuffs are first examined, and then the compressive strength of Portland cement is compared with pozzolanic cement to determine the pozzolanic activity of these volcanic tuffs.

\section{Geological Context}

The volcanic tuffs of Senegal-Oriental in Mako area dating from Birimian (about 2.3 - $1.95 \mathrm{Ga}$ ) [3]-[8] [10] [15] [16] [19] [21] [33] [36]. They are descripted as pyroclastic rocks which are produced during a submarine explosive volcano (Figure 1).

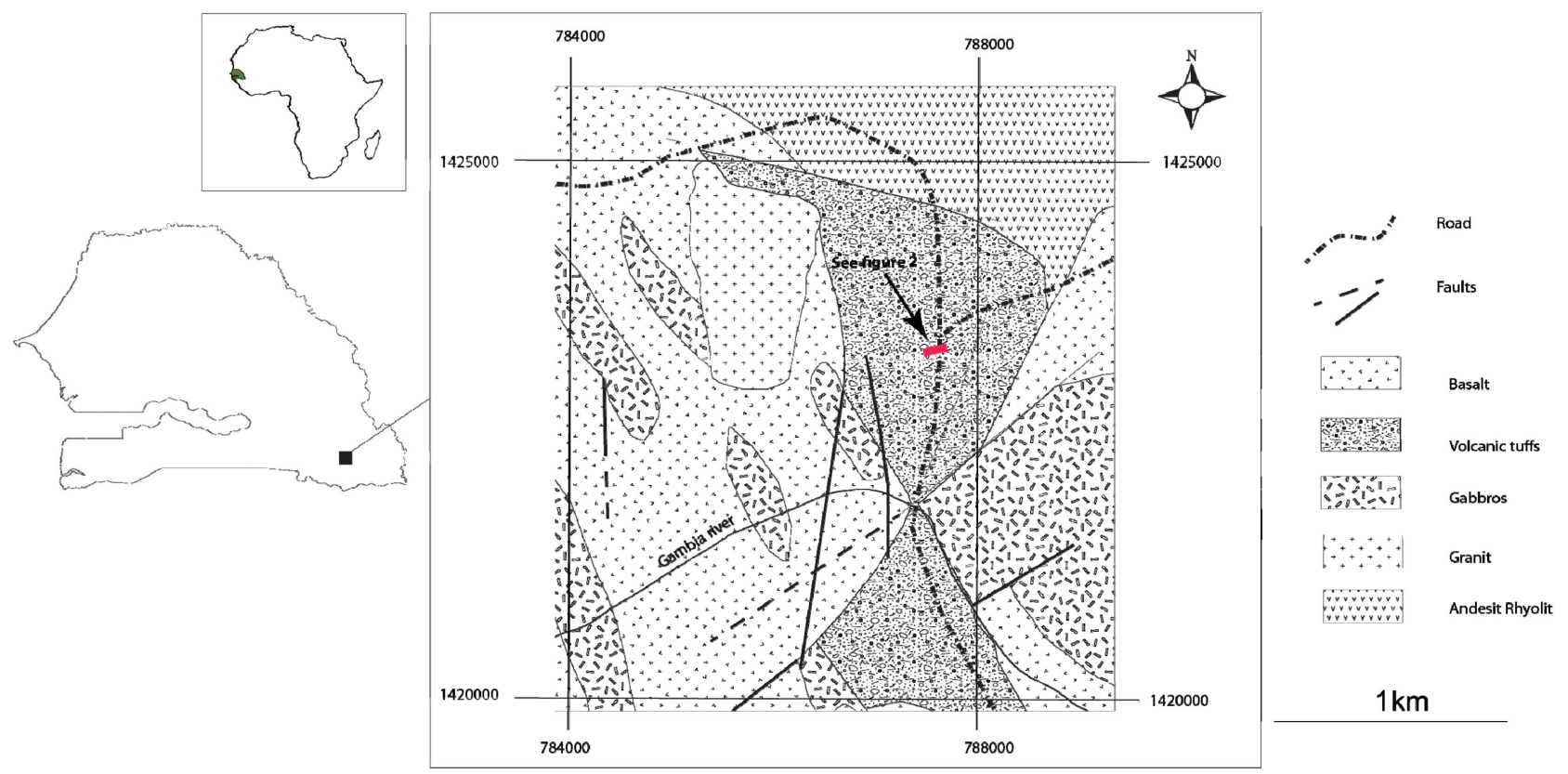

Figure 1. Geological context of the volcanic tuffs. We can see. 
A cross section oriented ENE-WSW (Figure 2) shows volcanic tuffs of 50m of thick, over bedded by metasediment and lava flow. All these formations are metamorphosed under green schist-facies conditions [3] [4] [5] [6] [8] [15] [36]. The volcanic tuffs are exposed along the road on several kilometres (Figures $1-3)$.
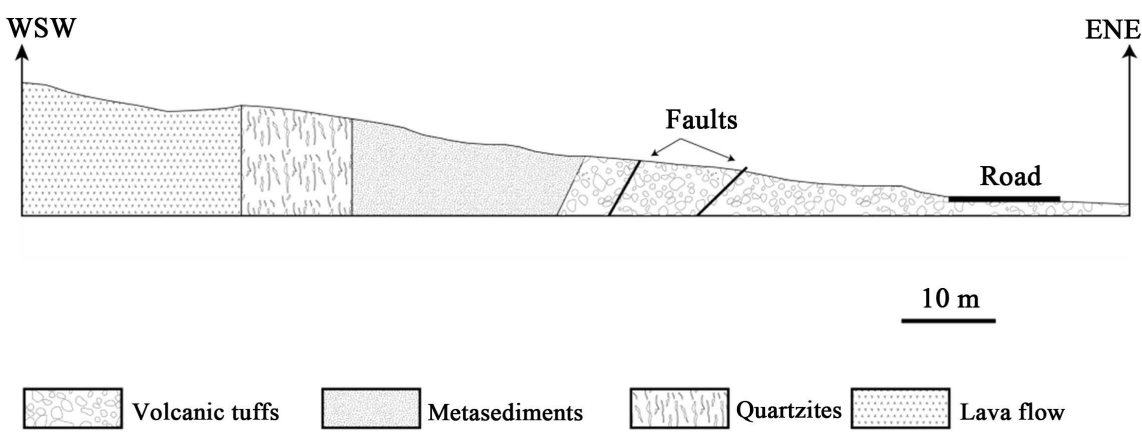

Figure 2. Geological profile on Figure 1 showing the context of taking place of the volcanic tuffs.

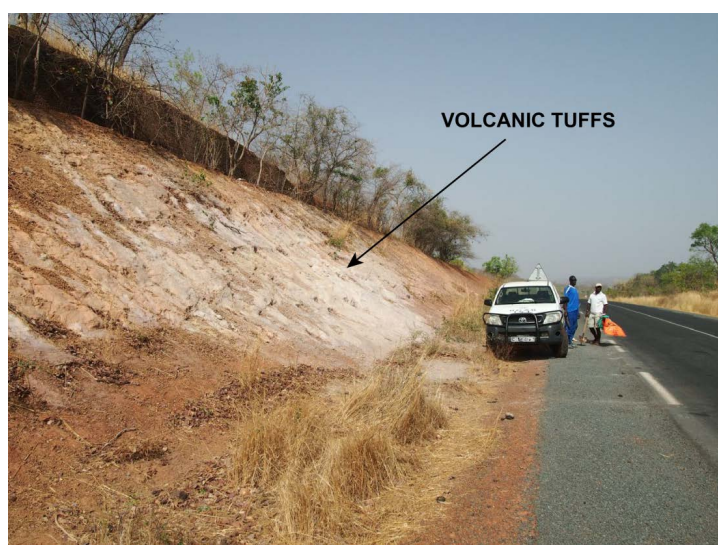

Figure 3. Outcrop of the volcanic tuffs on the side of the road. The volcanic tuffs are stripped to build the road.

\section{Material and Method}

\subsection{Material}

Clinker, gypsum and volcanic tuffs are the main components used in this study.

\section{Clinker}

Clinker or Portland Cement Clinker obtained by burning calcareous and clayey materials.

\section{Gypsum}

Gypsum is added to clinker as a set regulator. It is hydrated calcium sulphate in chemical form and plays a very important role in controlling the rate of hardening of the cement.

Portland cement (PC)

Portland cement obtained by pulverizing gypsum (5\%) and clinker (95\%) (Figure 4). 


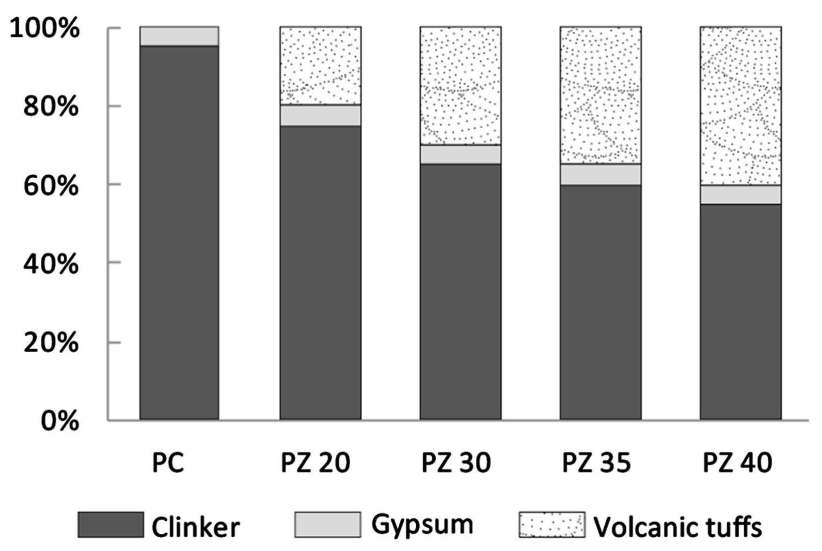

Figure 4. Percentage of constituents of the cements. PC: Portland cement, PZ: Pozzolanic cement.

\section{Volcanic tuffs}

Samples of volcanic tuffs are obtained from a deposit located in Mako (Figure 3), the Kedougou district of Senegal-Oriental (Senegal). Representative samples amounting to a total of $100 \mathrm{~kg}$ were collected from.

\section{Pozzolanic cements (PZ)}

Four categories of cements are manufactured according to formulations defined on Figure 4.

Cements are obtained grinding clinker, gypsum and volcanic tuffs.

\subsection{Method}

\subsubsection{Chemical Analysis}

Chemical analysis is carried out on clinker, gypsum, volcanic tuffs and cements to determine major elements composition. For each element a homogeneous laboratory sample is crushed and analysed according to [34]. The chemical analysis is an alkali fusion followed by a hydrochloric acid attack. Silica is quantified by gravimetry method. Oxides like $\mathrm{SiO}_{2}, \mathrm{Al}_{2} \mathrm{O}_{3}, \mathrm{CaO}, \mathrm{MgO}, \mathrm{Fe}_{2} \mathrm{O}_{3}$ and $\mathrm{Al}_{2} \mathrm{O}_{3}$ are quantified by complexometric titration. The loss on ignition (LOI) is determined by calcinations.

\subsubsection{Physical Analysis}

The volcanic tuffs are analysed with X-ray diffraction to determine minerals and amorphous or vitreous phase. Pozzolanic activity is proportional to the vitreous phase in the cement [13] [30].

The specific surface is measured only on the cements and the slightly crushed volcanic tuffs. The activity of a natural pozzolan, which is essentially determined by the reactive silica content, is also closely controlled by its specific surface area, chemical and mineralogical composition [1] [31] [40] [43].

Mechanical tests are the best method to evaluate the pozzolanic activity of cements. The tests are realized on standardized prismatic mortar bars $\left(4{ }^{*} 4{ }^{\star} 16\right.$ $\mathrm{cm})$. The composition of mortar is:

- $1350 \mathrm{~g}$ of standardized European sand (CEN EN 196 1), 
- $450 \mathrm{~g}$ of cement,

- 225 g of water.

The homogeneous mortars are conserved in mould for 24 hours in humid atmosphere.

After that, mortar bars are extract from mould and kept inside water at $20^{\circ} \mathrm{C}$.

Tests of compressive strength of mortar bars are realized at 2, 7, 14, 28 and 90 days after conservation inside water.

\section{Result and Discuss}

\subsection{Specific Surface of Volcanic Tuffs}

The specific surface of volcanic tuffs is $8895 \mathrm{~cm}^{2} / \mathrm{g}$. This shows that the volcanic tuffs are very fine. According to Largent (1975), the potential pozzolanic activity of matter depends on a high specific surface.

\subsection{Chemical Composition of Constituents}

Insoluble residue (IR) is a non-cementing material which is present in Portland cement. This residue material affects the properties of cement, especially its compressive strength [29]. Insoluble residue is not measured in the gypsum and volcanic tuffs. But in these constituents the proportion of IR is very important.

In the volcanic tuffs the silica content is $61.63 \%$ (Table 1) greater than $45 \%$. That gives them a potential pozzolanic activity [30] [38]. So, these natural pozzolans content a high of $\mathrm{SiO}_{2}+\mathrm{Al}_{2} \mathrm{O}_{3}$ (78.64\%) but a low content of $\mathrm{MgO}$ and $\mathrm{SO}_{3}$, then it can exhibit a high pozzolanic activity [1].

For the $\mathrm{CaO}, \mathrm{SiO}_{2}$ and $\mathrm{Al}_{2} \mathrm{O}_{3}$ the position of volcanic tuffs of Mako on Ternary Keil-Rankin diagram ([14]; [25]) is between volcanic glass and ashes (Figure 5).

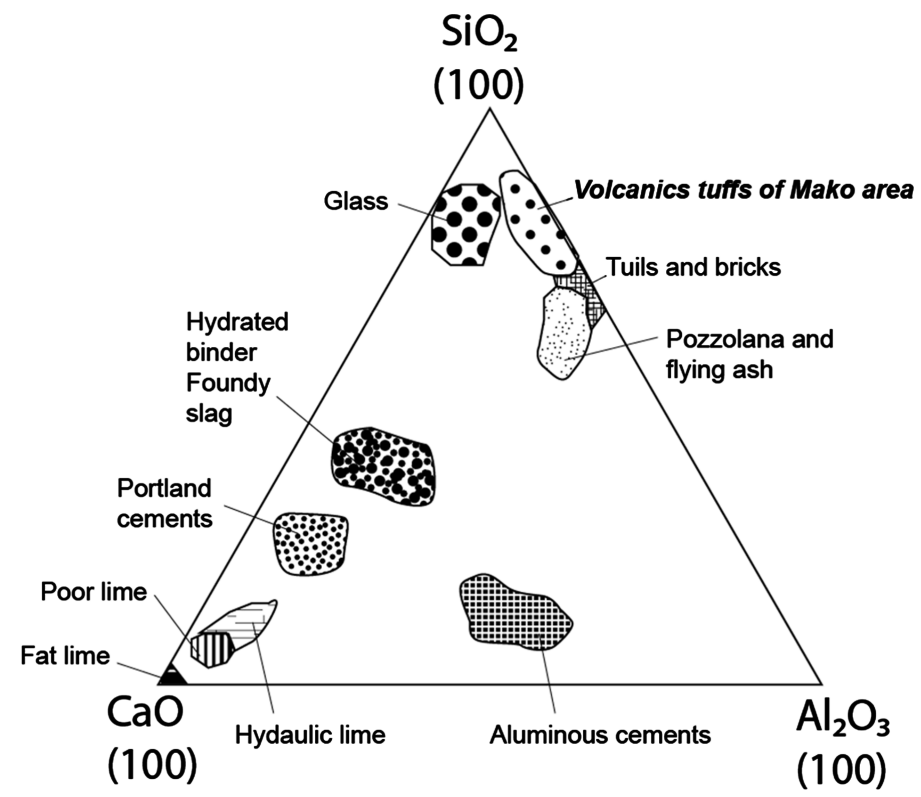

Figure 5. Position of Mako volcanic tuffs on Ternary Keil-Rankin diagram for the $\mathrm{CaO}-\mathrm{SiO}_{2}-\mathrm{Al}_{2} \mathrm{O}_{3}$. 
Table 1. Chemical composition of volcanic tuffs and gypsum.

\begin{tabular}{ccccccccc}
\hline & $\mathrm{LOI}$ & $\mathrm{SiO}_{2}$ & $\mathrm{SO}_{3}$ & $\mathrm{CaO}$ & $\mathrm{MgO}$ & $\mathrm{Fe}_{2} \mathrm{O}_{3}$ & $\mathrm{Al}_{2} \mathrm{O}_{3}$ & Total \\
\hline Volcanic tuffs & 5.58 & 61.63 & - & 1.23 & 0.51 & 11.71 & 17.01 & 97.67 \\
Gypsum & 25.85 & 6.08 & 48.02 & 15.69 & 1.31 & 0.60 & 0.65 & 98.2 \\
\hline
\end{tabular}

IR: Insoluble residue. LOI: Loss on ignition.

The difference between the tenors in lime and silica of volcanic tuffs is $67.31 \%$.

In the clinker the percentage of IR is $0.09 \%$ (Table 2). So, the measurements of free lime and $\mathrm{C}_{3} \mathrm{~S}$ mineral are respectively $0.3 \mathrm{~d} 57.74 \%$. This confirms the good quality of the clinker.

Volcanic tuffs are natural rocks of volcanic origin and composed of silica and alumina oxides but almost no lime. Therefore, they cannot develop hydraulic properties in the absence of hydrated lime.

Hydrated lime or material that can release it during its hydration (e.g. Portland cement) is then required to activate the natural pozzolans as a binding material [13].

The activity of a natural pozzolan, which is essentially determined by the reactive silica content, is also closely controlled by its specific surface area, chemical and mineralogical composition [29].

\subsection{X-Ray Diffraction of Volcanic Tuffs}

The result of X-Ray Diffraction shows the presence of quartz and other weathering minerals like kaolinite, muscovite, montmorillonite, muscovite (Figure 6). The quartz is very abundant. The hematite is also present. An important amorphous phase (A) gives hopes a potential pozzolanic activity by the volcanic tuffs. Because the amorphous phase could be potentially reactive with $\mathrm{Ca}(\mathrm{OH})_{2}$ of cement [13]. So, according to [30], the pozzolanic activity of matter is proportional of the present a morphous phase. Therefore the amorphous phase in these volcanic tuffs could be altered due to these ancient ages.

\subsection{Time of Grinding and Fineness of the Cements}

The cements are made by referring to the Figure 4. Grinding of the cements is executed at the same granulometry (Figure 7). That's why the time of grinding of the cements is inversely proportional to the percentage of addition of volcanic tuffs (Table 3). With the addition of $40 \%$ of volcanic tuff I, this time decreases of $50 \%$ comparatively to Portland cement.

\subsection{Specific Surface of Cements}

For the specific surface, the pozzolanic cements values higher than the one of Portland cements (Table 4). This fact shows the degree of fineness of the volcanic tuffs. The specific surface is proportional to the addition of volcanic tuffs. 


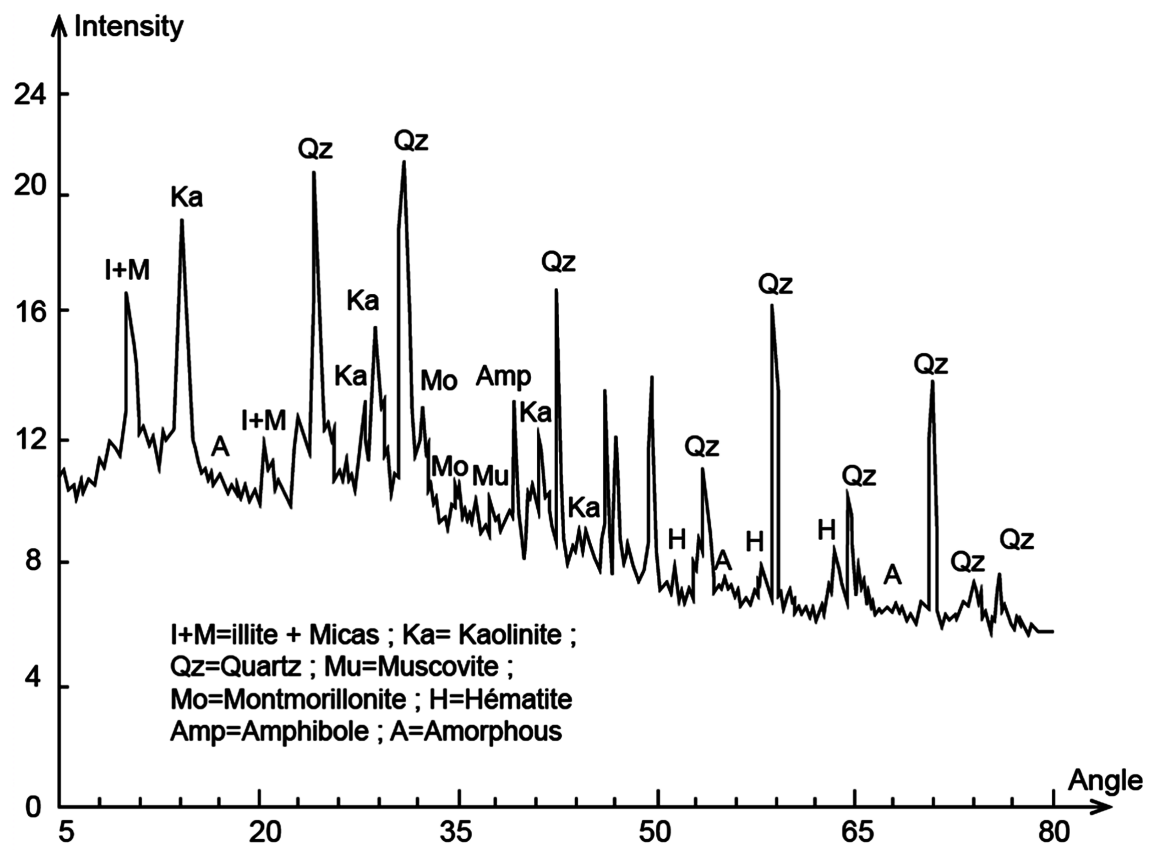

Figure 6. X-ray diagram of volcanic tuff of Mako area.

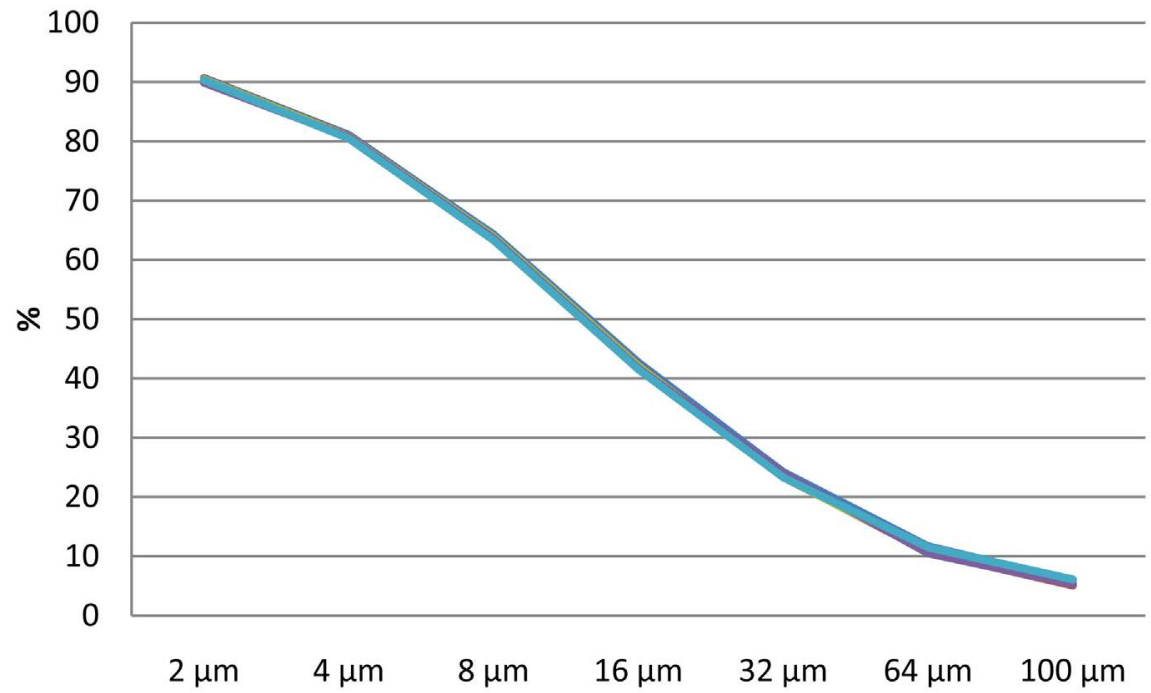

Figure 7. Fineness of cements. Cements are grinded at the same granulometry to avoid the influence of the fineness on compression strength.

Table 2. Chemical composition of the clinker.

\begin{tabular}{cccccccccccc}
\hline & LOI & IR & $\mathrm{SiO}_{2}$ & $\mathrm{SO}_{3}$ & $\mathrm{CaO}$ & $\mathrm{MgO}$ & $\mathrm{Fe}_{2} \mathrm{O}_{3}$ & $\mathrm{Al}_{2} \mathrm{O}_{3}$ & $\mathrm{CaOf}$ & $\mathrm{C}_{3} \mathrm{~S}$ & Total \\
\hline Clinker & 0.41 & 0.09 & 21.05 & 1.46 & 64.65 & 3.45 & 3.15 & 4.55 & 0.30 & 57.74 & 99.32 \\
\hline
\end{tabular}

IR: Insoluble residue, LOI: Loss on ignition, CaOf: free lime.

Table 3. Time of grinding of the cements.

\begin{tabular}{cccccc}
\hline Cements & PC & PZ 20 & PZ 30 & PZ 35 & PZ 40 \\
\hline Time of grinding (min) & 60 & 36 & 34 & 32 & 30 \\
\hline
\end{tabular}


Table 4. Specific surface of cements.

\begin{tabular}{cc}
\hline Cements & Specific surface $\left(\mathrm{cm}^{2} / \mathrm{g}\right)$ \\
\hline PC & 4212 \\
PZ20 & 5435 \\
PZ30 & 5472 \\
PZ35 & 5551 \\
PZ40 & 6005 \\
\hline
\end{tabular}

\subsection{Chemical Composition of Cements}

Chemical constituents like $\mathrm{SiO}_{2}, \mathrm{Fe}_{2} \mathrm{O}_{3}$ and $\mathrm{Al}_{2} \mathrm{O}_{3}$ increase proportionately with the addition of volcanic tuffs in blended cements (Table 5). But sulphate and loss on ignition contents are respectively lower than $3.5 \%$ and $5 \%$ required for a blended cement [1].

The measurement of the $\mathrm{CaOf}$ and $\mathrm{C}_{3} \mathrm{~S}$ in the clinker is respectively $0.2 \%$ and $47.26 \%$. Then potential reactive silica of volcanic tuffs could associate with $\mathrm{CaOf}$ of clinker. These pozzolanic reactions lead to the formation of additional hydrate minerals (C-S-H) with binding properties [2].

\subsection{Mechanical Performance of Blended Cements}

Mechanical performances at 2,7,14, 28 and 90 days age of mortars are illustrated in Table 6 and Figure 8. Generally, the compressive strength of cements increases with time. It is closely controlled by the addition of volcanic tuffs to the PC. We can deduce that the hydration of blended cements continues until 90 days. Which may due to the presence of new hydrated minerals formed by reaction between reactive silica from volcanic tuffs and free lime from clinker.

A consistent reduction in the compressive strength and rate of strength development of mortars is observed as the amount of the volcanic tuffs in the blended cement increased (Table 6 and Figure 8). The compressive strength of all mortars is higher than 16 and $32 \mathrm{~N} / \mathrm{mm}^{2}$ respectively at 7 and 28 days. Then, in reference on NF EN 197-1 these cements with addition of volcanic tuffs are pozzolanic cement belong to the class CEM IV/BP 32.5 .

Silicate minerals including feldspar, mica, hornblende, pyroxene and quartz or olivine present in volcanic rocks can easily undergo alteration to form secondary mineral phases such as clays, zeolites, calcite and various amphiboles [28]. The contribution of these secondary minerals to the pozzolanic activity of the volcanic tuffs is demonstrated by compressive strength growth.

Generally natural pozzolans include increased workability, decreased permeability increased resistance to sulphate attack, improved resistance to thermal cracking and increased ultimate strength and durability of concrete [9] [27] [40].

On that experience the volcanic tuffs are used directly without any pre-treatment. Therefore, it would be interesting to see the enhancing of the pozzolanic activity of these old volcanic tuffs pre-treating by thermal or chemical method. The 


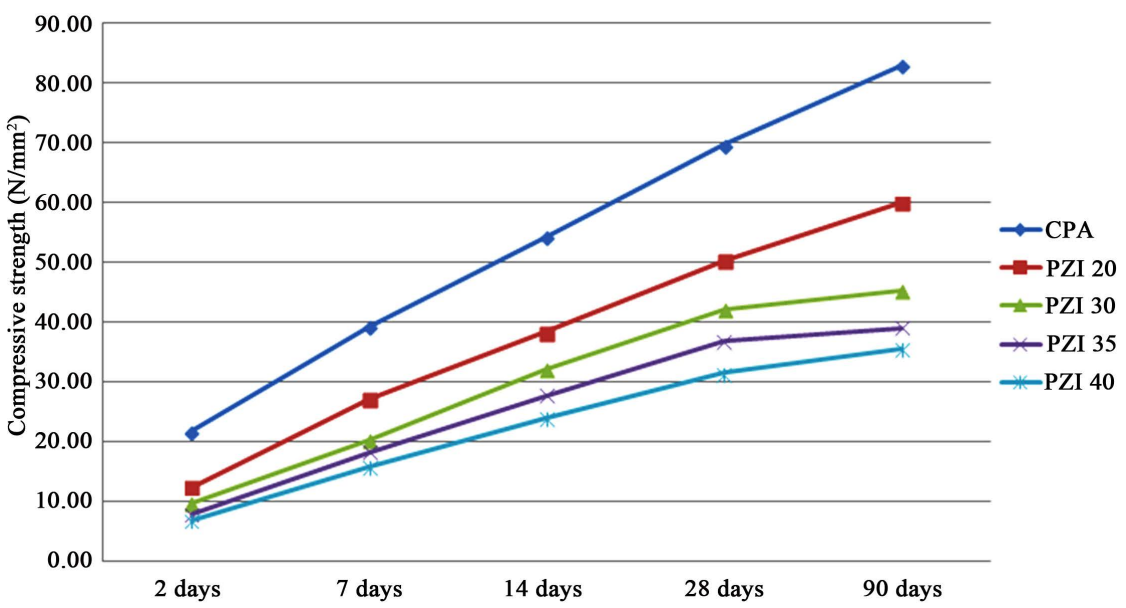

Figure 8. Compressive strength of cements.

Table 5. Chemical constituents of blended cements.

\begin{tabular}{cccccccccc}
\hline Cements & LOI & IR & $\mathrm{SiO}_{2}$ & $\mathrm{SO}_{3}$ & $\mathrm{CaO}$ & $\mathrm{MgO}$ & $\mathrm{Fe}_{2} \mathrm{O}_{3}$ & $\mathrm{Al}_{2} \mathrm{O}_{3}$ & Total \\
\hline PC & 1.72 & 0.32 & 21.06 & 3.64 & 61.54 & 3.62 & 3.23 & 3.77 & 98.9 \\
$\mathrm{PZ20}$ & 2.53 & 6.85 & 32 & 3.21 & 39.17 & 2.58 & 4.92 & 7.01 & 98.27 \\
$\mathrm{PZ30}$ & 2.6 & 9.41 & 37.13 & 2.63 & 32.13 & 2.23 & 5.12 & 7.23 & 98.48 \\
$\mathrm{PZ35}$ & 2.9 & 11.2 & 39.12 & 2.6 & 27.23 & 2.1 & 6.31 & 7.32 & 98.78 \\
$\mathrm{PZ} 40$ & 3.2 & 13.11 & 41.21 & 2.59 & 23.32 & 2.08 & 6.52 & 7.82 & 99.85
\end{tabular}

(IR: insoluble residue, LOI: Loss on ignition, CaOf: free lime).

Table 6. Compressive strength of cements $\left(\mathrm{N} / \mathrm{mm}^{2}\right)$.

\begin{tabular}{cccccc}
\hline Days in water & & & & & \\
Cements & 2 days & 7 days & 14 days & 28 days & 90 days \\
\hline PC & 21.8 & 39.2 & 54.2 & 69.7 & 82.9 \\
PZI 20 & 12.5 & 27.1 & 38.4 & 50.4 & 60.0 \\
PZI 30 & 9.7 & 20.3 & 32.1 & 42.2 & 45.2 \\
PZI 35 & 7.9 & 18.3 & 27.8 & 36.8 & 39.1 \\
PZI 40 & 7.0 & 15.9 & 24.1 & 31.5 & 35.5 \\
\hline
\end{tabular}

thermal method consists in heating the material at $800^{\circ} \mathrm{C}-900^{\circ} \mathrm{C}$ before the addition and grinding with the PC. The chemical method [42] is to activate the pozzolanic reaction with chemical activators such as $\mathrm{Na}_{2} \mathrm{SO}_{4}$ and $\mathrm{CaCl}_{2}$.

\section{Conclusions}

For the first time, the volcanic tuffs of Mako area in Senegal-Oriental are used to the pozzolanic activity. They are altered but they have physical and chemical characteristics of pozzolans. The time of grinding to obtain pozzolanic cements decreases with the addition of volcanic tuffs, significantly reducing the costs. So, the addition of volcanic tuffs could reduce the production of clinker, which may 
significantly reduce $\mathrm{CO}_{2}$ emissions in the atmosphere. The pozzolanic activity of the volcanic tuffs of Mako area has been shown by the compressive strength which increases until 90 days of conservation in water. In fact, the active silica from the volcanic tuffs reacts with the free lime of clinker to produce new hydrated minerals which participate in the increasing of the compressive strength.

For perspectives, the pozzolanic activity of the volcanic tuffs of Mako area could be improved by thermal method or chemical method using $\mathrm{Na}_{2} \mathrm{SO}_{4}$ or $\mathrm{CaCl}_{2}$.

\section{Acknowledgements}

The authors thank SOCOCIM Industry for allowing us to realize chemical and mechanical test of the raw materials and cements and its financial support.

\section{Conflicts of Interest}

The authors declare no conflicts of interest regarding the publication of this paper.

\section{References}

[1] Alp, I., Deveci, H., Süngün, Y.H., Yilmaz, A.O., Kesimal, A. and Yilmaz, E. (2009) Pozzolanic Characteristics of a Natural Raw Material for Use in Blended Cements. Iranian Journal of Science \& Technology, Transaction B, Engineering, 33, 291-300.

[2] Antiohos, S. and Tsimas, S. (2005) Investigating the Role of Reactive Silica in the Hydration Mechanisms of High Calcium Fly Ash/Cement Systems. Cement and Concrete Composites, 27, 171-181. https://doi.org/10.1016/j.cemconcomp.2004.02.004

[3] Bassot, J.P. (1966) Étude géologique du Sénégal Oriental et de ses confins GuinéoMalien. Thèse Clermont Ferrand, 1963 et mem BRGM, 40, 322 p.

[4] Bassot, J.P. (1969) Aperçu sur les formations Précambriennes et Paléozoïques du Sénégal Oriental. Bulletin de la Société Géologique de France, 11, 160-169. https://doi.org/10.2113/gssgfbull.S7-XI.2.160

[5] Bassot, J.P. and Caen-Vachette, M. (1984) Données géochronologiques et géochimiques nouvelles sur les granitoïdes de l'Est-Sénégal: implication sur l'histoire géologique du Birrimien de cette région. In: Klerkx, J. and Michot, J., Eds., African Geology, 191-209.

[6] Bassot, J.P. (1987) Le complexe volcanoplutonique calcoalcalin de la rivière Daléma (Est-Sénégal): Discussion de la signification géodynamique dans le cadre de l'orogénie éburnéenne (Protérozoïque inférieur). Journal of Earth Sciences, 25, 353-367.

[7] Bassot, J.P. (1997) Albitisation dans le Paléoprotérozoïque de l'Est Sénégal: Relations avec les minéralisations ferriferes de la rive gauche de la Falémé. Journal of Earth Sciences, 25, 353-367. https://doi.org/10.1016/S0899-5362(97)00109-7

[8] Bessoles, B. (1977) Le craton ouest africain. Géologie de l'Afrique. Mem B.R.G.M., 88, 402 p.

[9] Binici, H. and Aksoğan, O. (2005) Sulfate Resistance of Plain and Blended Cement. Cement and Concrete Composites, 28, 39-46.

https://doi.org/10.1016/j.cemconcomp.2005.08.002 
[10] Boher, M., Abouchamy, W., Michard, A., Albarède, F. and Arnd, N.T. (1992) Crustal Growth in West Africa at 2.1 Ga. Journal of Geophysical Research, 97, 345-369. https://doi.org/10.1029/91JB01640

[11] Bogue, R.H. (1952) La chimie du ciment Portland. Edition Eyrolles, Paris.

[12] Çavdar, A. and Yetgin, Ş. (2007) Availability of Tuffs from Northeast of Turkey as Natural Pozzolan on Cement, Some Chemical and Mechanical Relationships. Construction and Building Materials, 21, 2066-2071. https://doi.org/10.1016/j.conbuildmat.2006.05.034

[13] Chakchouk, A., Trifi, L., Samet, B. and Bouaziz, S. (2009) Formulation of Blended Cement: Effect of Process Variables on Clay Pozzolanic Activity. Construction and Building Materials, 23, 1365-1373.

https://doi.org/10.1016/j.conbuildmat.2008.07.015

[14] Deloy, F.X. (1993) Hydraulicité et pouzzolanicité. Bulletin de liaison des laboratoires des ponts et chaussées, 184, 94-95.

[15] Dia, A. (1988) Caractères et significations des complexes magmatiques et métamorphiques du secteur de Sandikounda-Laminia (Nord de la boutonnière de Kédougou; Est du Sénégal). Thèse d'état es Sciences Naturelles, Université Cheikh Anta Diop de Dakar, 348 p.

[16] Dia, A., Wanschmus, W.R. and Krôner, A. (1997) Isotopic Constraints on the Age and Formation of a Palaeoproterozoic Volcanic Arc Complex in the Kedougou Inlier, Eastern Senegal, West Africa. Journal of African Earth Sciences, 24, 197-213. https://doi.org/10.1016/S0899-5362(97)00038-9

[17] Diallo, D.P. (1994) Caractérisation d'une portion de croûte d'âge Protérozoïque inférieur du craton ouest africain: Cas de l'encaissant des granitoïdes dans le super groupe de Mako (Boutonnière de Kédougou). Implications géochimiques, Thèse d'état es Sciences Naturelles, Univ Cheikh Anta Diop, Dakar, Sénégal, 466 p.

[18] Diène, M. (2012) Evolution structural d'un segment du Craton Ouest Africain: Cas des formations paléoprotérozoïques du Supergroupe de Mako, Boutonnière de Kédougou-Kéniéba (Sud-Est du Sénégal). Thèse de Doctorat unique UCAD, 153 p.

[19] Diène, M., Gueye, M., Diallo, D.P. and Dia, A. (2012) Structural Evolution of a Precambrian Segment: Example of the Paleoproterozoic Formations of the Mako Belt (Eastern Senegal, West Africa). International Journal of Geosciences, 3, 153-165. https://doi.org/10.4236/ijg.2012.31017

[20] Diémé, A. (1991) Étude des performances de bétons hydrauliques à ciment nouveau (Ciment Portland à ajout pouzzolanique: $\mathrm{CPJ}$ ) et à granulat de type silexite: Utilisation des produits volcaniques du Cap-Vert et des déchets d'exploitation de la CSPT comme matériaux de substitution. Diplôme d'ingénieur, 59 p.

[21] Dioh, E. (1995) Caractérisation, signification et origine des formations birimiennes encaissantes du granite de Dioumbalou (Partie Septentrionale de la boutonnière de Kédougou-Sénégal Oriental). Thèse d'état es Sciences Naturelles, Univ Ch. Anta Diop, Dakar, Sénégal, 446 p.

[22] Djiba, Y. (1993) Importance économique des granulats au Sénégal et évaluation des performances d'un béton hydraulique à granulat de type silexite et à ciment Portland à ajout pouzzolanique. Diplôme d'ingénieur, $51 \mathrm{p}$.

[23] Dron, R. (1978) L'activité pouzzolanique. Bull. Liaison Labo. P. et Ch., 93, janv-févr, 66-69.

[24] Dron, R. and Brivot, F. (1977) Bases minéralogiques de la sélection des pouzzolanes.Bull. Liaison Labo. P. et Ch., 92, nov-dec, 105-112.

[25] Fisher, R.V. and Schmincke, H.U. (1970) Pyroclastic Rocks. Springer, Berlin. 
[26] Geoffray, J.M. and Valladeau, R. (1977) Morphologie et couleur des pouzzolanes. Bull. Liaison Labo. P. et Ch., 92, nov-déc,91-94.

[27] Ghrici, M., Kenai, S. and Said-Mansour, M. (2007) Mechanical Properties and Durability of Mortar and Concrete Containing Natural Pozzolana and Limestone Blended Cements. Cement and Concrete Composites, 29, 542-549. https://doi.org/10.1016/j.cemconcomp.2007.04.009

[28] Habert, G., Choupay, N., Montel, J.M., Guillaume, D. and Escadeillas, G. (2008) Effects of the Secondary Minerals of the Natural Pozzolans on Their Pozzolanic Activity. Cement and Concrete Research, 38, 963-975. https://doi.org/10.1016/j.cemconres.2008.02.005

[29] Kiattikomol, K., Jaturapitakkul, C. and Tangpagasit, J. (2000) Effect of Insoluble Residue on Properties of Portland Cement. Cement and Concrete Research, 30, 1209-1214. https://doi.org/10.1016/S0008-8846(00)00315-X

[30] Largent, R. (1975) Estimation de l'activité pouzzolanique. Recherche d'un essai. Bull. Liaison Labo. P. et Ch., 93, janv-fevr, 61-65.

[31] Massazza, F. (1993) Pozzolanic Cements. Cement and Concrete Composites, 15, 185-214. https://doi.org/10.1016/0958-9465(93)90023-3

[32] Ndiaye, M. (2000) Caractérisation des tufs volcaniques du secteur de Mako (Boutonnière de Kédougou-Sénégal-Oriental) en vue de leur utilisation dans un essai de fabrication de ciment pouzzolanique à l'échelle de laboratoire. Mém. DEA, Université C. A. Diop de Dakar, 150 p.

[33] Ndiaye, P.M., Dia, A., Vialette, Y., Diallo, D.P., Ngom, P.M., Sylla, M., Wade, S. and Dioh, E. (1997) Données pétrographiques, géochimiques et géochronologiques nouvelles sur les granitoïdes du Paléoprotérozoïque du supergroupe de Dialé-Daléma (Sénégal-Oriental): Implications pétrogénétiques et géodynamiques. Journal of African Earth Sciences, 25, 193-208. https://doi.org/10.1016/S0899-5362(97)00098-5

[34] NF EN 196-2-Méthodes d'essai des ciments: Analyses chimiques des ciments.

[35] Ngom, P.M. (1985) Contribution à l'étude de la série birimienne de Mako dans le secteur aurifère de Sabodala (Sénégal-Oriental). Thèse $3^{\text {ème }}$ cycle, Univ, Nancy I, 135 p.

[36] Ngom, P.M. (1995) Caractérisation de la croûte birimienne dans les parties centrales et méridionales du supergroupe de Mako: implications géochimiques et pétrogénétiques. Thèse d'état es Sciences Naturelles, Univ Cheikh Anta Diop, Dakar, Sénégal, $243 \mathrm{p}$.

[37] Niang, M. (1990) Propriétés des liants pouzzolaniques. Cas particulier des matériaux volcaniques des Mamelles. Diplôme d'ingénieur IST, No. 19, 59 p.

[38] Pichon, H., Gaudon, P., Benhassaine, A. and Eterradossi, O. (1996) Caractérisation et quantification de la fraction réactive dans les pouzzolanes volcaniques. Bull. Liaison Labo. P. et Ch., 201, janv-fevr, 29-37.

[39] Richardson, I.G. and Groves, G.W. (1997) The Structure of the Calcium Silicate Hydrate Phases Present in Hardened Pastes of White Portland Cement/Blast-Furnace Slag Blends. Journal of Materials Science, 32, 4793-4802. https://doi.org/10.1023/A:1018639232570

[40] Rodriguez-Camacho, R.E. and Uribe-Afif, R. (2002) Importance of Using the Natural Pozzolans on Concrete Durability. Cement and Concrete Research, 32, 1851-1858. https://doi.org/10.1016/S0008-8846(01)00714-1

[41] Sall, M. (1988) Caractérisation de l'activité pouzzolanique des matériaux volcani- 
ques: Exemple du volcanisme des Mamelles (Sénégal). Diplôme d'ingénieur IST, No. 14,79 p.

[42] Shi, C. and Day, R.L. (2001) Comparison of Different Methods for Enhancing Reactivity of Pozzolans. Cement and Concrete Research, 31, 813-818.

https://doi.org/10.1016/S0008-8846(01)00481-1

[43] Terzibaşığlu, N. (1995) Usability of Andesite in Production of Trass Cements. Proc. Industrial Minerals Symp., Izmir, 1-7.

[44] Türkmenoğlu, A.G. and Tankut, A. (2002) Use of Tuffs from Central Turkey as Admixture in Pozzolanic Cements Assessment of Their Petrographical Properties. Cement and Concrete Research, 32, 629-637. https://doi.org/10.1016/S0008-8846(01)00734-7

[45] Young, J.F. (1998) Cement-Based Materials. Current Opinion in Solid State and Materials Science, 3, 505-509. https://doi.org/10.1016/S1359-0286(98)80016-8 